\author{
KatARZYNA ŁOBACZ \\ University of Szczecin, Poland \\ Ewa Matuska \\ Pomeranian University in Slupsk, Poland
}

\title{
Project-Based Learning in Entrepreneurship Education: a Case Study-Based Analysis of Challenges and Benefits
}

\begin{abstract}
The Project-Based Learning (PBL) approach to teaching, although well-known, is still little used. However, its fundamental educational value is increasingly often emphasised, consisting of identifying real problems, shaping pro-active attitudes in students, and creating links between educational institutions and various types of external organisation. The article aims to present the challenges and benefits related to the teaching process in PBL based on the analysis of the LINCE project, implemented according to the same methodology simultaneously in Poland, Spain and Italy. Based on the results of the research and the literature review, recommendations are made regarding the possibility of broader use of PBL methodology in entrepreneurship education. The work is based on an exploratory research approach, using qualitative research methodology and case study technigue.
\end{abstract}

Keywords: case study; education; entrepreneurship; project-based learning

Received: 23 January 2020

Accepted: 21 September 2020

\section{Suggested citation:}

Łobacz, K., Matuska, E. (2020). Project-Based Learning in Entrepreneurship Education: a Case Study-Based Analysis of Challenges and Benefits. Przedsiębiorczość - Edukacja [Entrepreneurship Education], 16(2), 86-98. doi: 10.24917/20833296.162.7

\section{Introduction}

Project-Based Learning (PBL), recently popularised quite intensively in Poland (Spałek, 2011; Zdonek, 2017), represents one of the student-centred educational approaches, i.e. which are oriented towards more in-depth learning and acquiring the skills necessary in the 21st-century labour market. It fits very well into the paradigm of learning based on the acquisition of competencies which has been recommended in the European Union by the European Qualification Frame (EQF) directive since 2008 and is strengthening its position especially in the field of vocational and higher education (Sturing et al., 2011). The key is the highly pragmatic orientation of PBL methodology addressing current 
topics relevant and important from the point of view of academic work and/or the social, cultural or economic environment. The learning process based on PBL methodology is comprehensive, integrated and emotional. Due to these advantages, PBL facilitates the acquisition of practical competencies, shapes entrepreneurial attitudes, and facilitates the creation of business networks.

The article aims to present the teaching process in the PBL trend, as well as the challenges and benefits associated with it. Based on a critical review of the literature and personal research - an analysis of three specific PBL initiatives undertaken simultaneously in Poland, Spain and Italy as part of the LINCE project - recommendations were made regarding the applicability of PBL methodology in entrepreneurship education.

\section{Project approach - characteristics, benefits, challenges}

J. Dewey, who promoted the idea of 'learning by doing' at the end of the $19^{\text {th }}$ century (Dewey, 1938/1997), can be considered as the precursor of the philosophy from which PBL methodology grew. This thesis was supported by E. Dale, who presented a learning model known as the 'cone of experience' (Dale, 1969). This cone is shown in Figure 1.

The basis of Dale's 'cone' includes the actual experiences of the learner who actually 'does something or acts' (e.g. their life experiences or those gained during simulations). The centre of the 'cone' refers to the imaginary function of the student (modelling reality), and its peak means an abstract situation based on knowledge of the standard language codes of the teacher and the student. In the learner, along with the height of the cone, there is a systemic loss in the level of understanding and recall of the conveyed content. This means that the most lasting learning outcomes are achieved by carrying out real activities and tasks in the course of the learning process. This is what PBL learning is all about.

Figure 1. The model of the cone of experience according to E. Dale

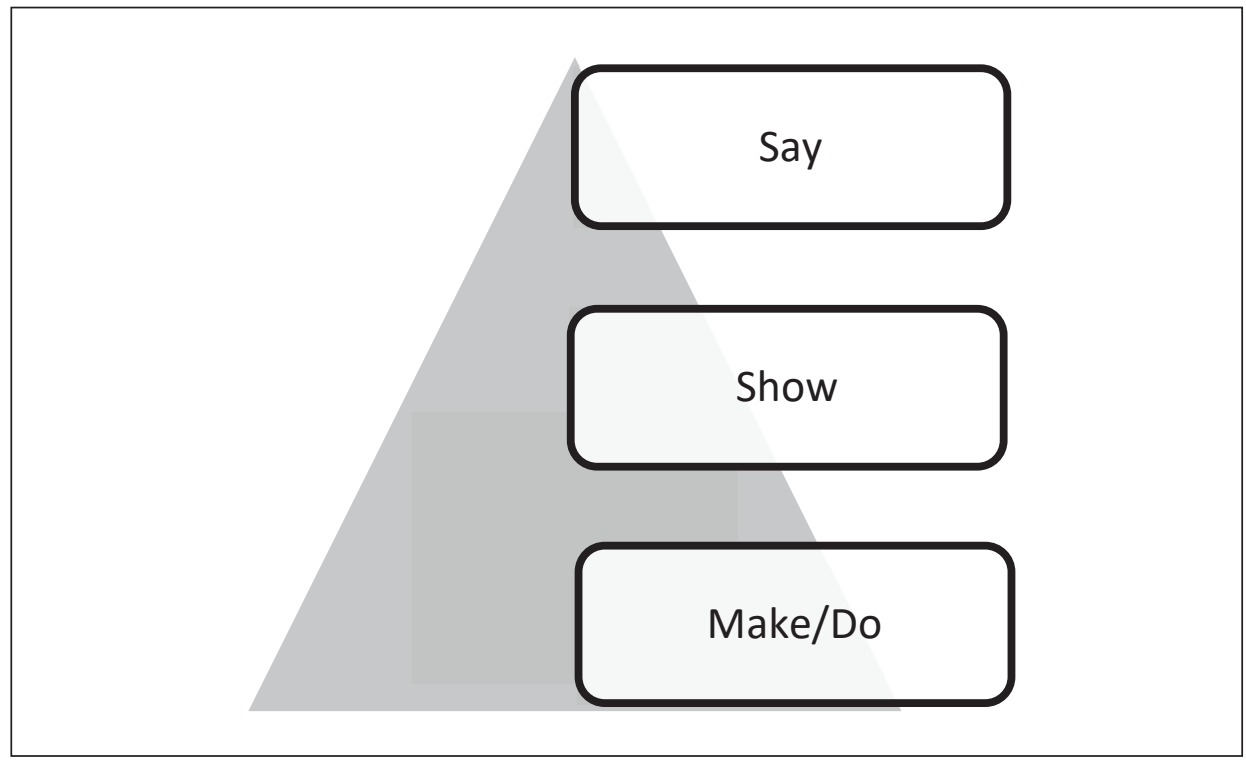

Source: Dale (1969) 
D. Kirkpatrick developed the 'project method', which is considered the first formal version of the PBL model but not identical to it (Peterson, 2012). The key to the 'project method' is "the activities undertaken by students around a topic that really interested them" (Ravitch, 2000: 179), i.e. its cognitive and motivational aspect.

The main principles of PBL prescribe the use of a project as the primary teaching tool and define the positions of pupils/students as active actors in the learning process (student-centred approach). The key elements of PBL include defining goals, conveying the learning content based on standards, and developing practical conceptual, technical and social skills (cf. Zdonek, 2017: 411).

J.W. Thomas (2000) identified five essential features of projects in the PBL approach: 1. centrality, 2. driving question, 3. constructive inquiry, 4. autonomy, and 5. realism. The author emphasised the importance of pupils'students' cooperation, self-reflection and public presentation of the project results. The uniqueness of learning in the PBL approach lies in the construction of a final product in the form of a 'specific artefact' (Helle, Tynjälä, Olkinuora, 2006) which triggers a new understanding (insight) in the learner, updates their knowledge, shapes new attitudes and activates the processed way of presentation of its solution, e.g. using films, photos, models, etc. (Holubova, 2008).

Contemporary research on PBL methodology focuses on the issues of 'learning about learning' (Bransford, Brown, Cocking, 1999) and its advantages when confronted with the competency requirements for $21^{\text {st }}$-century employees (Pellegrino, Hilton, 2012). While working on the project, the pupil/student acquires basic knowledge and skills essential for the labour market, namely: 1 . defines and solves a significant practical problem, challenging, but within the range of their intellectual and practical abilities; 2. learns systematic, goal-oriented action, the use of assessment standards on efficiency and control of the achieved results; 3 . is a subject in a relationship with a teacher, actively seeking information, asking inquisitive questions, and overcoming obstacles on the way to a goal; 4 . presents the achieved results in public space, confronting their reception by others, and learning how to use them in practice. Hence, it is only a step to the possible commercialisation of the newly acquired knowledge and experience, i.e. to entrepreneurship.

Based on a review of the academic literature on PBL methodology (cf. Condliffe et al., 2017), it can be concluded that it is based on the shaping of transferrable competencies and general 'project principles'. It usually refers to what has already been learned, but also opens up opportunities for the acquisition of new transferrable and specialist competencies. There is an agreement between different authors dealing with PBL issues in the following areas: the time horizon of a typical PBL module, the range of roles/positions taken by students in the learning process, and the criteria for assessing results. Moreover, many authors emphasise that modern information and communication technology (ICT) supports the successful implementation of PBL methodology and increases its effectiveness (Krajcik, Shin, 2014; Ravitz, Błażewski, 2014).

So far, no consensus has been reached on a canon of PBL principles. There is consensus, however, that PBL fits as a complementary methodology to traditional learning methods. There is also no uniform, comprehensive vision of PBL methodology, which makes it challenging to evaluate a single case of applying the project methodology in terms of its compliance with the PBL concept. Implementation in the qualification framework of individual EU member states requires the definition of learning outcomes at each 
level of education in the form of a competency profile that the graduate will have developed after completing the selected learning path. Some authors (cf. Sturing et al., 2011) indicate that while specifying competencies by educators, in the form of new effects on knowledge, skills and the so-called social competency, has become a routine practice, the question of research on the theoretical mechanisms of acquiring competences by pupils/ students during the learning process remains open.

Part of this gap could be successfully filled by research undertaken in relation to the possibility of using PBL methodology, especially in the field of vocational/practical education, and most of all, in entrepreneurship education.

\section{Methodological assumptions of the application of the PBL approach in teaching entrepreneurship}

The benefits and challenges of teaching PBL methodology are based on the example of an analysis of three educational projects implemented simultaneously in Poland, Italy and Spain as part of the joint educational initiative LINCE between October 2017 and September 2019. The research material consisted of archival documentation and direct interviews with those involved in their implementation. The use of the so-called exploratory single case study, according to the approach of R.K. Yin (2017), is aimed at identifying the subject of the research and facilitated the definition of its content and strategy. The choice of the case study technique was justified by the opportunity to use the so-called instrumental case study, as interpreted by R.E. Stake (1995), according to which the analysed case can successfully play an auxiliary role in the description of a problem significant from the researcher's point of view.

The aim of this research was an attempt to assess the scope and value of the use of PBL methodology in indirect entrepreneurship education in the course of the implementation of a standard study program. The starting point in establishing the research assumptions was the use of a theoretical framework describing the value of the PBL approach in education, presented in the previous section.

The following research questions were posed: What was the teaching process in each of the PBL initiatives? How have students and educational organisations benefited from PBL? What were the challenges faced to obtain the planned benefits? To what extent have entrepreneurial competencies been developed?

\section{The teaching process in a project approach - a case study}

The LINCE educational initiative was implemented in three independent centres in Poland, Spain and Italy, each with a professional or academic educational profile. The work of students was based on the application of the principles of PBL methodology and on project cycle management (PCM), as recommended by the European Commission (2004). The stages and activities used in the learning process described are presented in Figure 2.

In the course of the PBL process in LINCE, four phases were distinguished: commencement, planning, implementation and completion, each covering several activities.

The educational goal was defined as strengthening entrepreneurial skills through the implementation of projects aimed at solving real problems using modern digital tools. PBL included the selection and implementation by pupils/students of a project that responds to 
Figure 2. PBL methodology in the LINCE projects

\begin{tabular}{|c|c|}
\hline PHASES & ACTIONS \\
\hline \multirow[t]{4}{*}{ PHASE 1} & Starting the project \\
\hline & "Analysis and understanding of partners' needs \\
\hline & " Defining educational expectations \\
\hline & » Undertaking project activities \\
\hline \multirow[t]{9}{*}{ PHASE 2} & Planning of activities \\
\hline & " Defining goals and learning outcomes \\
\hline & " Determining the scope of activities in the project \\
\hline & " Establishing the stages of project development \\
\hline & "Establishing a project team \\
\hline & » Assignment of tasks \\
\hline & "Defining the communication mechanism in the project \\
\hline & » Evaluation of owned resources \\
\hline & "Scheduling events inaugurating the start of the project \\
\hline \multirow[t]{7}{*}{ PHASE 3} & Project implementation \\
\hline & » Coordinating the work of the team \\
\hline & » Internal communication \\
\hline & » Organisation of meetings \\
\hline & » Introducing corrections to the plan \\
\hline & »Change management \\
\hline & " Managing expectations \\
\hline \multirow[t]{4}{*}{\begin{tabular}{|l|} 
PHASE 4 \\
\end{tabular}} & Project closure \\
\hline & » Summary of the project \\
\hline & " Archiving of documents \\
\hline & » Summary of conclusions from the learning process \\
\hline
\end{tabular}

Source: authors

the real and current needs of non-governmental organisations. An additional element was the development of digital skills in the creation of audio-visual materials, the use of media and electronic tools, and the development of awareness on regional heritage protection.

Educational institutions, in cooperation with local organisations, selected specific tasks to be implemented, which included three stages of activity: researching local cultural heritage, creating digital interactive materials, creating digital stories. The country-specific projects are presented in Table 1.

In all cases, the learning process followed a uniform pattern. Although the exact way in which the work was carried out differed from unit to unit due to the diverse nature of the projects, the different operating models of academic units, or the heterogeneous groups of students, there are expected benefits and challenges in applying project-based learning. They are discussed below in chronological order of the successive stages of the learning process in the PBL model used, while their benefits and challenges are summarised in Table 2. 
Table 1. Projects implemented in individual countries in the teaching process using PBL methodology $^{1}$

\begin{tabular}{|l|c|c|c|}
\cline { 2 - 4 } \multicolumn{1}{c|}{} & $\begin{array}{c}\text { Local cultural heritage } \\
\text { research }\end{array}$ & $\begin{array}{c}\text { Digital interactive } \\
\text { materials }\end{array}$ & $\begin{array}{c}\text { Create } \\
\text { digital stories }\end{array}$ \\
\hline Poland & $\begin{array}{c}\text { Valuable for science, } \\
\text { technology and art under } \\
\text { the Griffin logo }\end{array}$ & $\mathrm{x}$ & $\begin{array}{c}\text { The history of the } \\
\text { development of the Griffin } \\
\text { logo in Pomerania }\end{array}$ \\
\hline Spain & $\begin{array}{c}\text { 3D reconstruction of } \\
\text { the Torre del Homenaje } \\
\text { region }\end{array}$ & $\begin{array}{c}\text { Morigerati Pease Ambiente } \\
\text { - interactive film } \\
\text { Tames from the area of } \\
\text { Torre del Homenaje }\end{array}$ & $\begin{array}{c}\text { Following the traces of } \\
\text { history in Italy - digital } \\
\text { tourist information }\end{array}$ \\
\hline
\end{tabular}

Source: authors based on: García et al. (2019)

The first and necessary phase of project-based teaching was the preparation, and this included many activities such as those carried out in cooperation with non-governmental institutions. It took time before the actual teaching process could begin. Within Phase 1: Starting the project, concerning the initiation of the educational process, three crucial activities were distinguished: a. analysis and understanding of partners' needs; b. defining educational expectations; c. undertaking project activities. As the assumption was to implement projects for the needs of specific organisations and local communities, acquiring appropriate partners and understanding their needs was an essential element of the process. It was important to define the needs of partners accurately and to communicate them effectively to the other parties. The challenge at this stage was to link current needs with the educational expectations set out in the programs of educational institutions which were usually aimed at developing the so-called transferrable competencies in conjunction with specialist competencies in a given field.

In the educational activities analysed, in all three cases ideas for projects were developed long before their actual implementation in the educational process. A good practice applied by educational organisations was to use currently implemented regional development projects and select from among them those that could constitute the basis for building local partnerships. For teaching purposes, the following transferrable competencies related to shaping entrepreneurial attitudes and skills were acquired: 1) effective time management, 2) effective interpersonal communication and the use of feedback, 3) teamwork and task coordination, 4) conducting consultations and negotiations with various groups of stakeholders, 5) analytical and critical thinking, problem-solving and creating alternative solutions, 6) responsibility, independence, building trust and credibility by performing assigned tasks.

Besides, the learning objectives were focused on developing specific technical competencies enabling the implementation of projects in a selected field: 1) storytelling supported with IT tools, 2) narrative communication carried out using various audio-visual formats, 3) researching historical, cultural, artistic and social-economic references, 4) planning and conducting interviews and talks with various groups of stakeholders in

\footnotetext{
${ }^{1}$ The detailed course of the teaching process and the developed results are available on the website: http:// proyecto-lince.com/
} 
order to collect and select the necessary source materials, 5) using various IT programs to process selected materials to obtain the final product digitally, 6) building awareness of the importance of copyright and various funding sources for processing and publishing. All these competencies were included as learning outcomes common to projects in each of the partner countries.

Planning of activities (Phase 2) included proper planning of the implementation process of the selected project in the educational organisation. The main aim of this stage was to obtain the maximum possible consistency between the expected project results and the learning objectives and outcomes assumed in the educational program. Concerning the learning outcomes, the following features of the project were planned: scope and allocation of tasks, obtaining resources necessary for their implementation, and determination of communication methods. A huge challenge was to incorporate the newly defined educational framework into the structures and programs of existing organisations. In addition to the guidelines on the use of PBL methodology, they had to include the use of broadly defined audio-visual tools. This many times required a multidisciplinary approach, in which the roles of several teachers were combined, and the tasks were carried out in several subjects simultaneously or sequentially.

The next stage (Phase 3 ) of the project was the actual project implementation. At this phase, it was necessary to take into account the timing of individual tasks and available resources, as well as to establish appropriate working teams with assigned roles and functions for individual people. It was also necessary to establish control mechanisms, in particular methods of monitoring and communication between various parties involved in the project implementation, and then to systematically carry out these activities. Project management and coordination of the work of individual teams required constant communication, including with the use of remote working tools. The educational role of this phase was to master the control procedures and evaluate the correct course of the project as well as shape a flexible and constructive approach in the event of deviations from the adopted plan. In the PBL model used, it is defined as management change skills and the taking of corrective actions. These types of attitudes are crucial in initiating later entrepreneurial activities of pupils/students.

In the LINCE projects, a particular challenge for the coordinators was managing the schedule and coordinating the work of many teams. It was necessary to organise specialist training in the use of modern tools for creating digital materials, provided thanks to the funds from the project. To improve internal communication, the Dropbox cloud was used as an element integrating all the results. Other tools included Skype and IONOS mailing as channels of digital communication, launched in order to clarify any ambiguities. In internal communication, project coordinators also used Google Cloud tools: Gmail, Google Drive and Kanbanchi, as tools for organising deadlines, goals, results and the division of tasks among team members. In the activity of managers of academic units and the tasks performed by students under the supervision of teachers, Google educational tools such as Google Drive, Google Forms and Google Classroom were widely used to record the performance of individual tasks, to set project milestones and document its results.

The last step of the PBL model implemented was Phase 4: Project closure. It covered various types of operation necessary for the proper completion of the project, i.e. archiving documents and summarising conclusions resulting from the learning process. Archiving of documentation may be considered an additional activity. However, from 


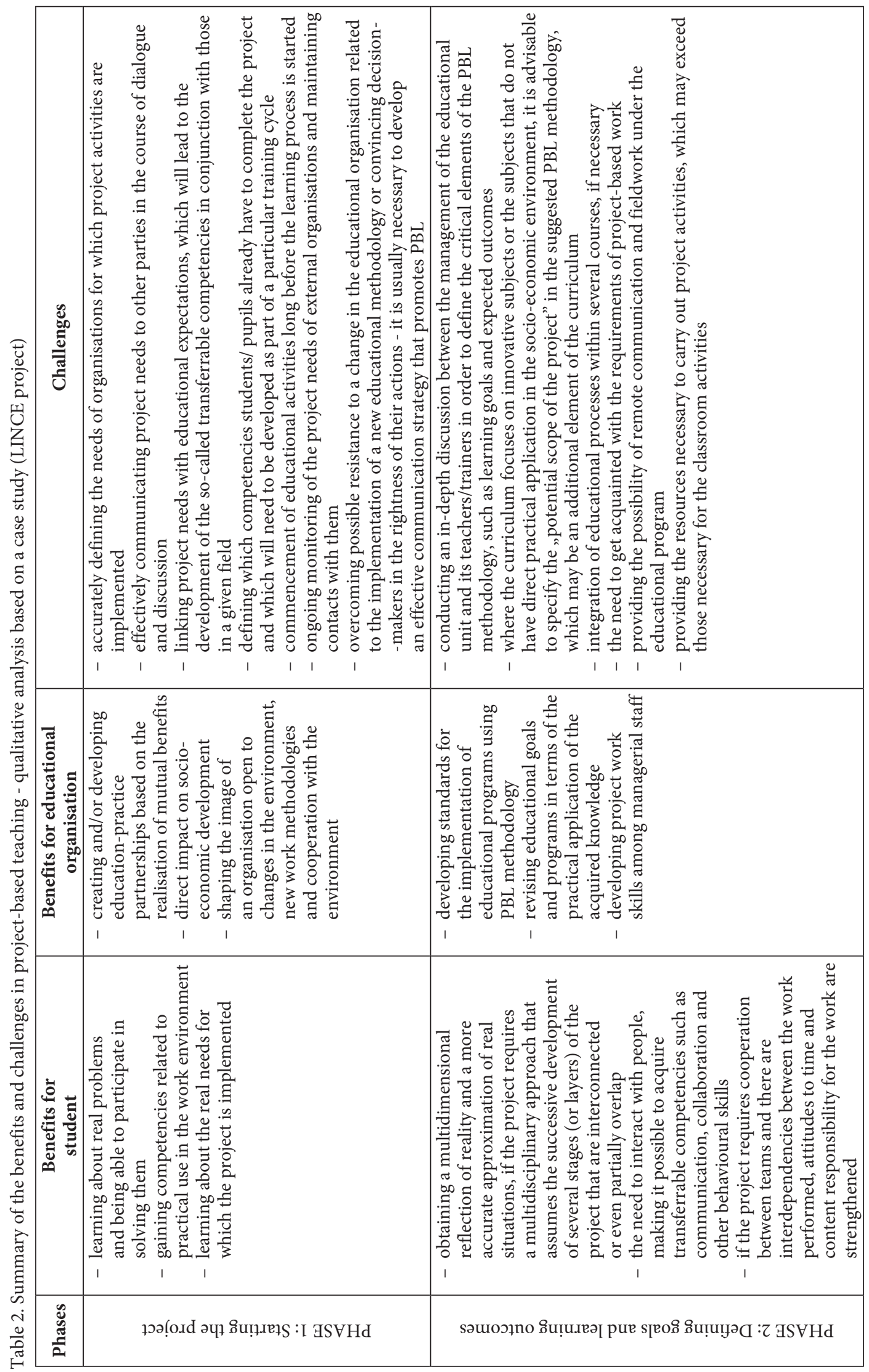




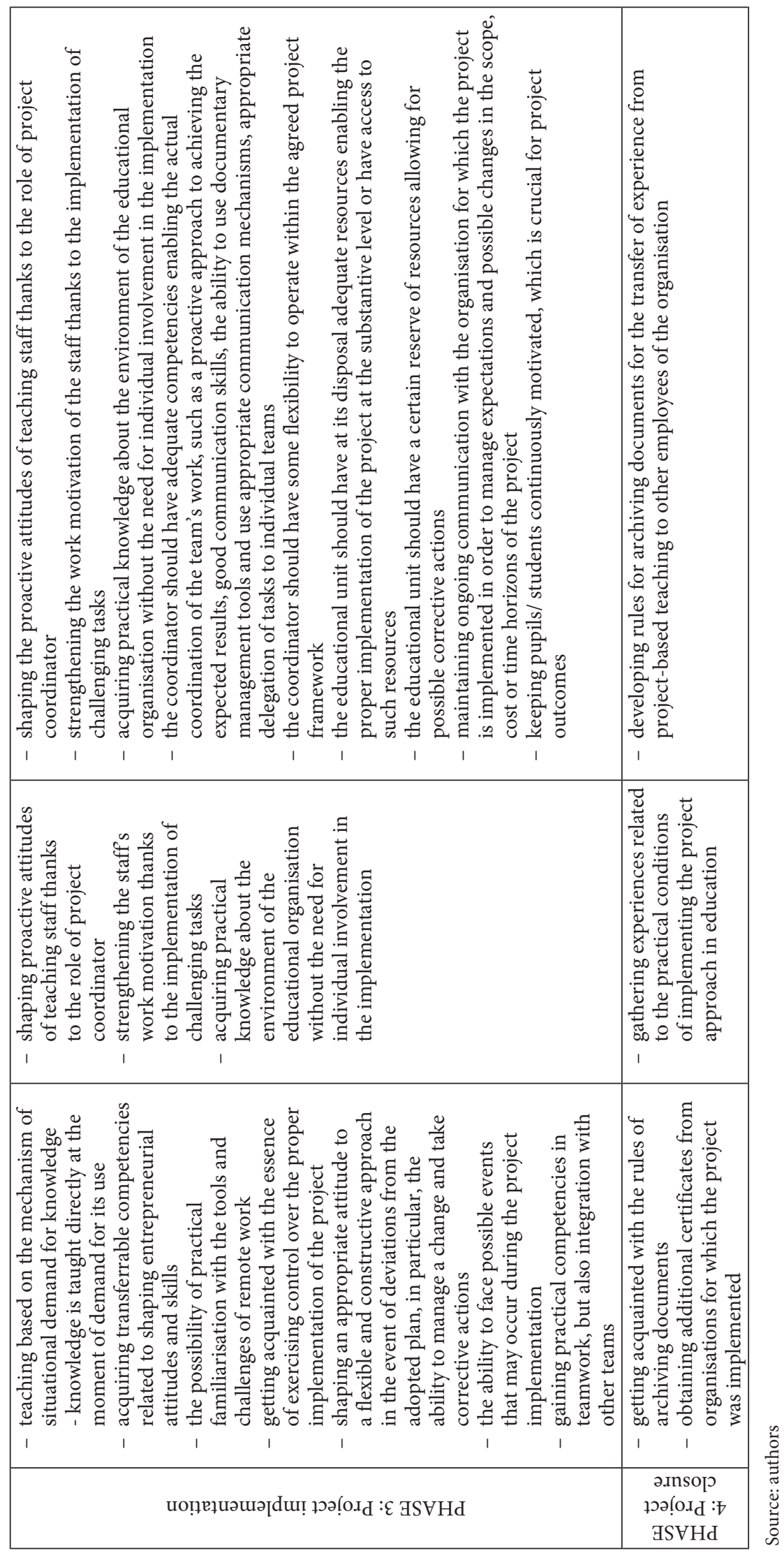


the experience of the LINCE project, it can be concluded that it is worth treating it as the final stage of regular management and control procedures, as it enables the accumulation of knowledge and thus improvement of the PBL teaching process.

The implementation of the pilot teaching process using the PBL approach allowed for the definition of real challenges related to its implementation in existing educational organisations, as well as the determination of possible benefits related to shaping entrepreneurial attitudes for the student and the educational organisation. A detailed summary of the individual stages of the described learning process is presented in Table 2.

\section{Conclusions and recommendations for the use of PBL in entrepreneurship education}

Implementation of PBL methodology according to the logic of so-called project cycle management (PCM) has brought students and educational organisations several benefits. It triggered initiative, focused on achieving goals and measurable results, taught planning and implementation, engaged various resources and used indicators of achieved effectiveness. It strongly engaged students emotionally, motivated them to persistence in action and built their sense of agency. It allowed practising self-presentation skills and experience satisfaction while presenting the results. These benefits, cognitive, social and behavioural, made a direct reference to the educational content related to shaping entrepreneurial orientation.

The analysis of the benefits and challenges related to the implementation of educational activities in the field of PBL methodology shows that project teaching requires much commitment, but also brings several benefits for students, teachers and the organisation itself. There are undisputed benefits for the organisations for which the project is implemented and for society. These are additional beneficiaries of the activities undertaken.

An in-depth analysis of the benefits to pupils/students reveals that as a result of project

Figure 3. Areas where PBL methodology is used in terms of entrepreneurship education

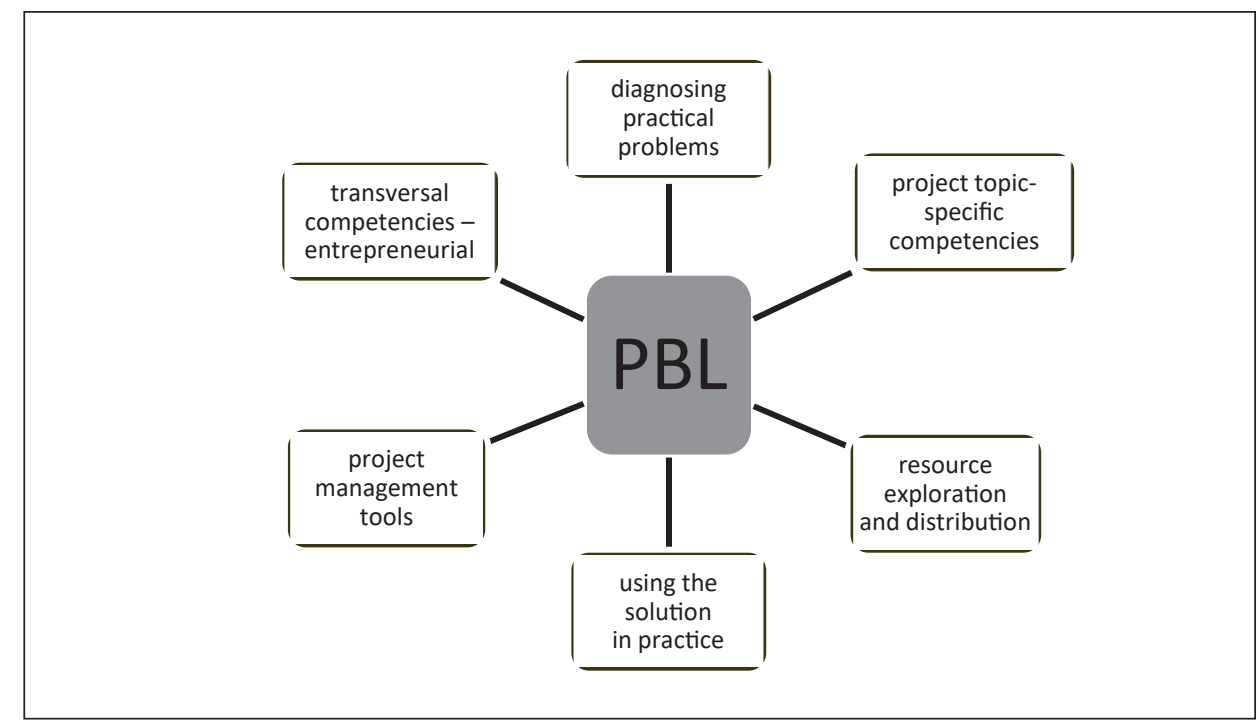

Source: authors 
learning, they acquire some competencies that are important in undertaking subsequent entrepreneurial activities. The combination of these competencies with an understanding of the needs of the socio-economic environment and the acquisition of hard 'technical' competencies is a good starting point for the development of the knowledge-based enterprises that are the engine of the modern economy. Thus, thanks to PBL methodology, an interdisciplinary approach is obtained, including an economic, sociological, psychological or even an anthropological perspective (cf. Brzozowska, 2016: 459).

For the article, the context of the PBL methodology process was only partially drawn from the described case study to emphasise its connection with the process dimensions of the entrepreneurship issue. What is also crucial is the relationship between PBL methodology and the modelling of subjective behaviour of a pupil/student (they are independent but work in a team - like a future entrepreneur) and the dimension of the processes of creating a new enterprise (goal-oriented, e.g. acquiring and allocating resources, evaluating results and their presentation). In the traditional model of entrepreneurship education, pupils/students are mainly equipped with theoretical economic and financial knowledge (Siemieniak, Rebiasz, 2019), and less importance is attached to acquiring practical skills or shaping entrepreneurial attitudes. This gap may be filled by PBL methodology, which comprehensively develops various types of practical skills when solving a specific problem/issue of a theoretical or practical nature (Zdonek, 2017).

In relation to the analysed case study, thanks to the application of the PBL approach in the formula of the project (PCM) and the project procedure, a strong effect of compliance with the general characteristics of entrepreneurial activity was achieved. The kind of partnership established in the project was also of crucial importance in terms of promoting entrepreneurial attitudes in students. It was a strategic relationship between educational and civil society institutions: industrial and tourist, cultural organisations and enterprises from the audio-visual sector operating in the area of the local/regional impact of educational institutions.

Figure 3 presents an attempt to illustrate the heuristic value of PBL methodology concerning entrepreneurship education in the case study.

Based on the analysis, it can be concluded that the PBL educational approach supports the development of entrepreneurial competencies, and may also facilitate future decisions on self-employment and planning one's own business. Importantly, it allows for the development of entrepreneurial attitudes, including within specialist subjects, not directly focused on the content related to the functioning of enterprises. Therefore it can be successfully used by technical universities and vocational schools.

The use of PBL methodology in the implementation of educational projects useful for various types of civil society institutions (cultural, economic, public) combines at least three key elements: 1) Educational outcomes, in line with the curriculum (competencies in terms of knowledge, skills and attitudes specific to the project topic); 2) Technical effects (skills to operate project tools, PCM, including the use of IT tools); and 3) Entrepreneurial effects (transferrable competencies in the field of knowledge, skills and attitudes related to entrepreneurship).

Additional elements with connotations related to entrepreneurship are 4) Ability to diagnose practical problems (social sensitivity, perceiving market niches); 5) The ability to recognise and allocate resources necessary for the implementation of the project; and 6) The ability to use the results of the project in practice (contribution to the commercialisation of knowledge and experience). 
There is a conviction that there is a need to continue research on the value of the PBL educational approach in promoting entrepreneurial attitudes. It is also important to recognise other challenges and possible limitations of the PBL methodology application for all stakeholders. It signals the need for further qualitative and quantitative research to verify the correctness and features of the phenomena explored in this article.

\section{References}

Bransford, J.D., Brown, A.L., Cocking, R.R. (1999). How people learn: Brain, mind, experience, and school. Washington, DC: National Academy Press.

Brzozowska, A. (2016). Teorie przedsiębiorczości. In: Klincewicz, K. (ed.), Zarządzanie, organizacje i organizowanie - przeglad perspektyw teoretycznych. Warszawa: Wydawnictwo Naukowe Wydziału Zarządzania Uniwersytetu Warszawskiego, 459-471.

Condliffe, B., Quin, J., Visher, M.G., Bangser, M.R., Drohojowska, S., Saco, L., Nelson, E. (2017). Project-Based Learning. A Literature Review-Working Paper. MDRC. Retrieved from: http://live-buckinstitute.pantheonsite.io/sites/default/files/2019-01/MDRC\%2BPBL\%2BLiterature\%2BReview.pdf

Dale, E. (1969). Audio-Visual Methods in Teaching. 3rd Ed. New York: Holt, Rinehart \& Winston.

Dewey, J. (1938/1997). Education and Experience. New York: Touchstone.

European Commission. (2004, March). Aid delivery methods. Vol. 1. Project Cycle Management Guidelines. Europe Aid Cooperation Office. Retrieved from: https://ec.europa.eu/europeaid/sites/ devco/files/methodology-aid-delivery-methods-project-cycle-management-200403_en_2.pdf

García, L.M, Cook, S., Łobacz, K., Matuska, E., Rosania, V., Santaniello, A., Colace, F., Santaniello, D. (2019). Illustrated Methodological Guide. LINCE. Retrieved from: https://drive.google.com/ file/d/1K9eLoFeYWb7v1p_O1MjC8qy_OZizkXNv/view

Gartner, W. (1985). A conceptual framework for describing the phenomenon of new venture creation. Academy of Management Review, 10(4), 696-706.

Helle, L., Tynjälä, P., Olkinuora, E. (2006). Project-based learning in post-secondary education - theory, practice and rubber slingshots. Higher Education, 51, 287-314.

Holubova, R. (2008). Effective teaching methods - project-based learning in physics. US-China Education Review, 12(5), 27-35.

Krajcik, J.S., Shin, N. (2014). Project-based learning. In: R.K. Sawyer (ed.), The Cambridge handbook of the learning sciences. New York: Cambridge University Press, 275-297.

LINCE. (2019, 10 November). Retrieved from: http://proyecto-lince.com/pl/index.php

My PBLWorks. (2019, 10 November). 21st Century Skills Framework. Retrieved from: http://www.bie. org/object/document/21st_century_skills_framework

Pellegrino, J.W., Hilton, M.L. (2012). Education for life and work: Developing transferable knowledge and skills in the $21^{\text {st }}$ century. Washington, DC: National Academies Press.

Peterson, B.W. (2012). Uncovering the progressive past: The origins of project-based learning. UnBoxed: A Journal of Adult Learning in Schools, 8. Retrieved from: http://gse.hightechhigh.org/unboxed/ issue8/uncovering_the_progressive_past/

Ravitch, D. (2000). Left-back: A century of failed school reforms. New York: Simon and Schuster.

Ravitz, J., Blazevski, J. (2014). Assessing the role of online technologies in project-based learning. Interdisciplinary Journal of Problem-Based Learning, 8(1), 65-79.

Research Summary on the Benefits of PBL. (2019, 10 November). Retrieved from: http://www.bie.org/ object/document/research_summary_on_the_benefits_of_pbl

Siemieniak, P., Rembiasz, M. (2019). Importance of knowledge in the process of shaping the entrepreneurial attitudes of young people. MATEC Web of Conferences 290, MSE 2019 13010. doi: 10.1051/ matecconf /20192901 MSE 201913010

Spałek, S. (2011). Nauczanie przez projekty jako metoda kształcenia menadżerów XXI wieku zgodnie z zapotrzebowaniem przedsiębiorstw. Zarządzanie i Edukacja, 79, 5-11. 
Stake, R.E. (1995). The Art of Case Study Research. Sage Publications Inc., Series NULL.

Sturing, L., Biemans, H.J.A., Mulder, M., de Bruijn, E. (2011). The Nature of Study Programmes in Vocational Education: Evaluation of the Model for Comprehensive Competence-Based Vocational Education in the Netherlands. Vocations and Learning, 4, 191-210.

The Difference Between Projects And Project-Based Learning. (2019, 10 November). Retrieved from: // www.teachthought.com/learning/project-based-learning/difference-between-projectsand-project-based-learning/

Thomas, J.W. (2000). A review of research on project-based learning. San Rafael, CA: The Autodesk Foundation.

Yin, R.K. (2017). Case Study Research and Applications: Design and Methods. SAGE Publications, Inc; Sixth edition.

What is Project-Based Learning (PBL)?. (2019, 10 November). Retrieved from: http://www.bie.org/ about/what_pbl 27

Why Project Based Learning. (2019, 10 November). Retrieved from: http://www.bie.org/about/why_pbl Zdonek, I. (2017). Wykorzystanie Project Based Learning w edukacji klasy kreatywnej. Zeszyty Naukowe Politechniki Śląskiej. Seria: Organizacja i Zarządzanie, 102, 407-422.

Katarzyna Łobacz, PhD, University of Szczecin, Faculty of Economics, Finance and Management, Institute of Management, Department of Business Management. University Professor, author of academic publications, especially in the field of innovation, knowledge transfer and commercialisation, academic entrepreneurship, competence-based development; manager of many research projects; with a strong emphasis on practical applications of knowledge through expertise, development of centres supporting innovation and entrepreneurship, development of students career pathways, etc.

ORCID: https://orcid.org/0000-0001-5038-1022

\section{Address:}

Uniwersytet Szczeciński

Wydział Ekonomii, Finansów i Zarządzania

Katedra Zarządzania Przedsiębiorstwem

ul. Cukrowa 8

71-004 Szczecin, Polska

e-mail: katarzyna.lobacz@usz.edu.pl

Ewa Matuska, PhD, Pomeranian University in Slupsk, Institute of Safety and Management, Chair of Management. University Professor, author of academic publications, especially in the field of human resource management and organisational psychology, especially in the area of competence management, career management and educational coaching concepts, trainer and project manager of innovative educational projects as well as regional development projects, including international ones.

ORCID: https://orcid.org/0000-0003-1334-3574

\section{Address:}

Akademia Pomorska

Katedra Zarządzania

ul. Kozietulskiego 6

76-200 Słupsk, Polska

e-mail: ewa.matuska@apsl.edu.pl 